\title{
OBSERVATIONS ON BIRDS FROM NORTHERN CANADA - 1975
}

JAMES D. RISING and FREDERICK W. SCHUELER. Dept. of Zoology, University of Toronto, Toronto, Ont. M5S IAl

This note reports some observations we made during the summer of 1975 that extend or confirm the known or breeding ranges of bird species in northern Canada. We list all records that are beyond the breeding ranges of Godfrey (1966). ${ }^{4}$ All observations of sparrows and introduced species are summarized in Table 1, the former because of the special attention we gave them in our fieldwork, and the latter because of their ongoing incursions into the north.

The locations of our camps, and our dates at each site, are given in Table 1. D. M. Niles accompanied us at Ft. Chimo. Specimens are deposited in the Royal Ontario Museum and a copy of our field notes is deposited at the National Museum of Natural Sciences, Ottawa. Data on nesting birds have been separately summarized on North American Nest Record Cards or (if from Ontario) on Ontario Nest Records Scheme cards. Nomenclature follows Godfrey (1966), with one noted exception.

Our research was supported by a grant from the National Research Council of Canada to Rising.

RED-NECKED GREBE. We saw one carrying nesting material (weeds) in its bill on a pond by the CN Railroad track, 5 mi. S. Thompson Junction, Manitoba, 11 June. Not reported by Weber in $1973 .^{7}$

BLUE-WINGED TEAL. Several were seen at Yellowknife, on Niven Lake which is used for sewage disposal.

GREATER SCAUP. We saw a pair, apparently on territory, on a small pond near the Coppermine River, 20 and 22 June, but were unable to locate a nest. Godfrey showed this species' breeding range well south of Coppermine. ${ }^{4}$
GOSHAWK. We saw one between Yellowknife and Edzo, 18 June.

SHARP-SHINNED HAWK. We saw one at Yellowknife, (7 km NW Giant Mine), 19 June.

OSPREY. We saw an Osprey overhead at the Inuvik airport, 3 July, and D. M. Niles saw one at Fort Chimo, 9 June. Godfrey gave sight records north to Great Bear Lake and Fort Norman, NWT, and north to Great Whale River and Knob Lake, Quebec. ${ }^{4}$

KILLDEER. We saw two or three at Norman Wells (along the Mackenzie River) and two at Yellowknife (Niven Lake).

RING-BILLED GULL. We saw one adult at Yellowknife (Niven Lake), 25 June, and one adult at Norman Wells (town), 26 June. Godfrey mentioned the occurrence of non-breeding individuals north to Great Slave Lake."

COMMON NIGHTHAWK. Territorial ("booming") nighthawks were fairly common at Yellowknife (near airport).

BELTED KINGFISHER. We saw one at Yellowknife (North Arm, Great Slave Lake). 18 June, and two at Norman Wells (Mackenzie River).

ALDER FLYCATCHER. Empidonax alnorum. "Fee-bee-o"-singing birds were heard from several alder-willow thickets between Yellowknife and Edzo, 18 June. (See Eisenmann et al. for clarification of this nomenclature..$\left.^{2}\right)$

LEAST FLYCATCHER. We heard two singing at Gillam, and two singing at Norman Wells (town). Johnson considered Least Flycatchers uncommon breeders at Thompson, Manitoba Weber reported them as common. ${ }^{7}$ Roe heard them at Norman Wells." 


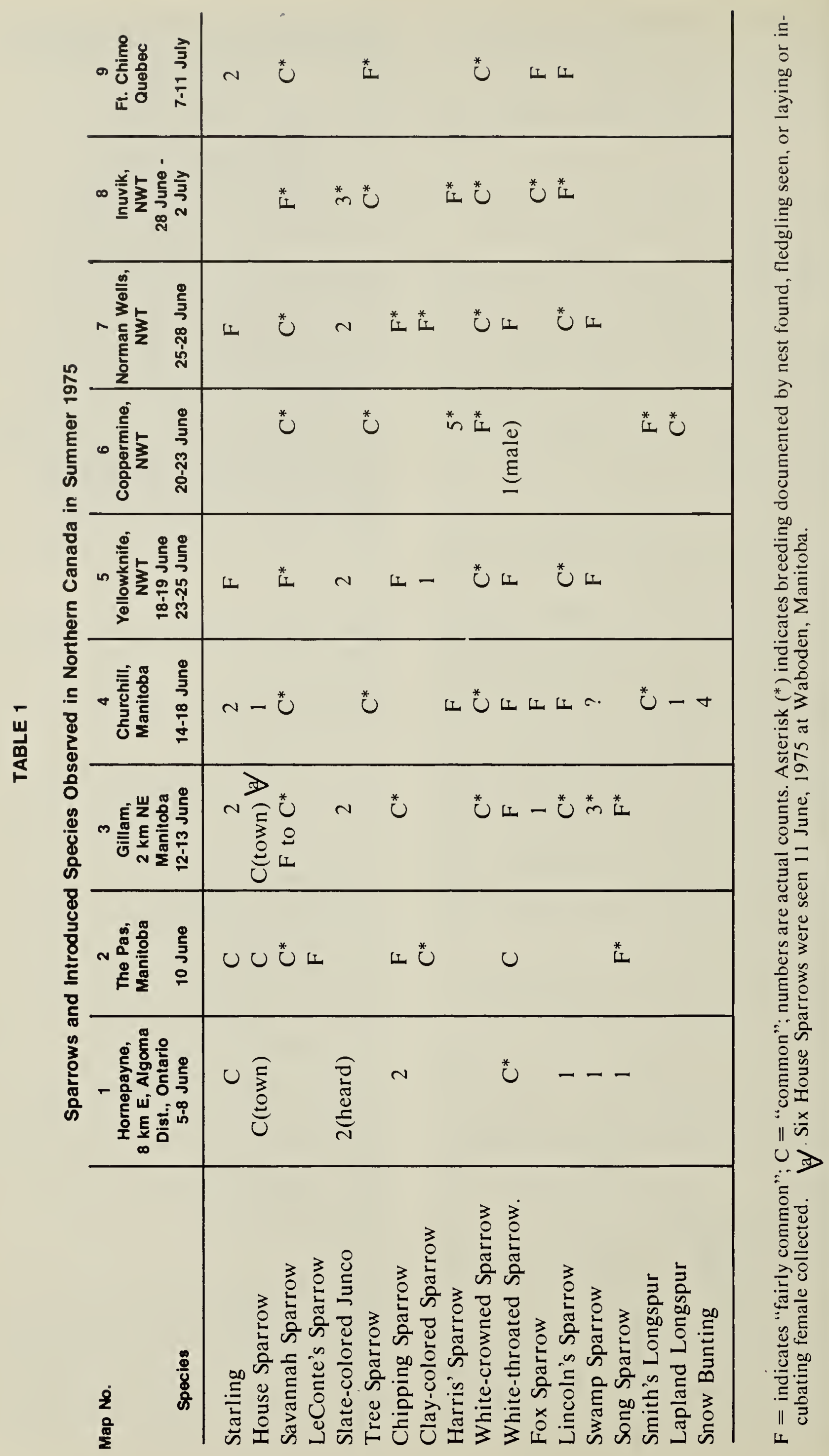

212

Blue Jay 


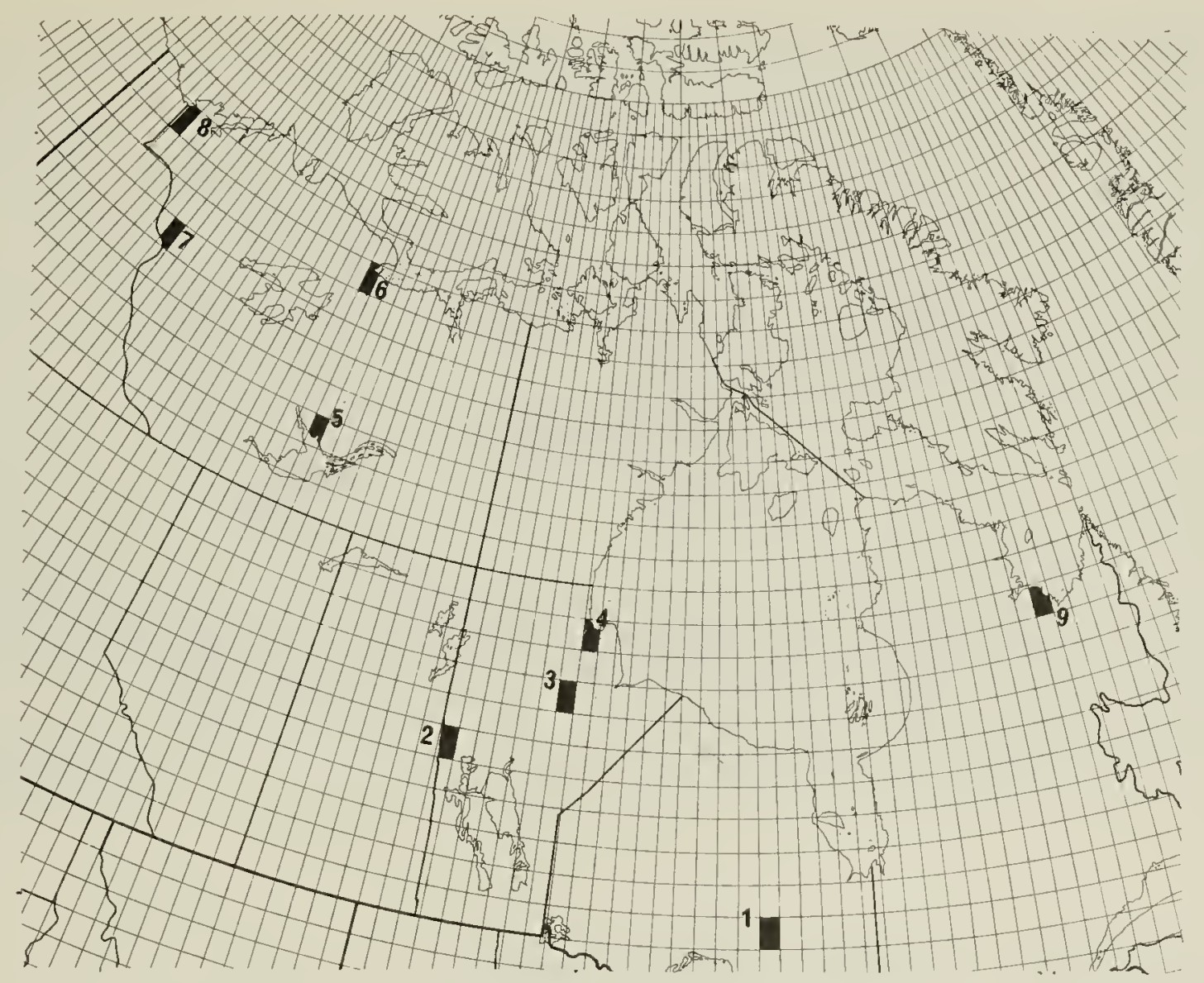

Numbers correspond to those in table on opposite page.

BARN SWALLOW. We saw one at Norman Wells (town), 27 June. Godfrey reported a nesting record at Fort Norman, NWT. ${ }^{3}$

GRAY-CHEEKED THRUSH. We saw and heard several in birch thickets at Coppermine.

SOLITARY VIREO. We saw three singing and apparently territorial males at Gillam, in spruce-jack pine-aspen woods. Johnson stated that this vireo is an uncommon breeder at Thompson": Weber found two singing there on 30 June, 1973.?

RED-EYED VIREO. We heard two singing at Gillam, and two singing at Norman Wells (town) Weber considered Red-eyed Vireos "fairly common" at Thompson ${ }^{7}$, and Godfrey mentioned records north to Fort Norman along the Mackenzie River. ${ }^{4}$

PHILADELPHIA VIREO. We took a pair at Gillman, 12 June. The female (ROM 124076) did not possess a brood patch; the male's (ROM 124075 ) left testis was enlarged to $4 \mathrm{x}$ $3 \mathrm{~mm}$

TENNESSEE WARBLER. Tennessee Warblers were singing commonly from spruces along the east branch of the
Mackenzie River at Inuvik, 30 June. Roe found them north to Fort Good Hope in the Mackenzie Valley. ${ }^{6}$

MAGNOLIA WARBLER. We found three singing males in spruce-jack pineaspen woods at Gillam. They were "fairly common" at Thompson, in 1973.

BLACKPOLL WARBLER. Blackpolls were singing fairly commonly in dense willow-birch thickets on the bluffs along the Coppermine River at Coppermine. Godfrey shows this species as breeding across the central NWT. ${ }^{4}$

PALM WARBLER. We found at least two pairs, and collected an incubating female (ROM 124415) in dwarf spruce-tamarack-Labrador tea thickets at the south end of the airport runway at Norman Wells. Roe reported autumnal sight records from Norman Wells. ${ }^{i}$

YELLOWTHROAT. We found several singing males at Gillam. Godfrey mentioned records north to central Manitoba, but neither Johnson nor Weber found them at Thompson. ${ }^{4}$ is

CLAY-COLORED SPARROW. We heard one singing from an alder thicket by the road, $11 \mathrm{~km}$ NW Yellowknife, 25 
June, and found at least "two pairs breeding (a female, ROM 124416, had an active incubation patch) in deciduous bushes at the south end of the Norman Wells airport, 26 June.

LINCOLN'S SPARROW. We found a pair breeding (the female, ROM 124417 , had ruptured follicles and an active incubation patch) in a deciduous thicket along a stream through an old burn at the south edge of Inuvik, 1 July. Edwards and Weir reported the species at Inuvik. ${ }^{1}$

'EDWARDS, M. H. and R. D. WEIR. 1972. Lincoln's Sparrow at Inuvik, N.W.T. and Common Starling at Whitehorse, Yukom. Canadian FieldNaturalist $86(\mathrm{I}): 85$.
'EISENMANN, E. (and committee). 1973. Thirtysecond supplement to the Ainerican Ornithologists' Union Check-list of North American birds. Auk 90: 411-419.

"GODFREY, W. E. 1965. Range extensions of sorne birds in western Mackenzie. Canadian Field-Naturalist 79 (1): 34-38.

'GODFREY, W. E. 1966. The birds of Canada. National Museum of Canada Bulletin Number 203. 428 pp.

JOHNSON, J. W. 1970. A bird list for Thompson. Manitoha. Blue Jay 28 (1): 14-19.

"ROE, N. A. 1975. New records of hirds in westcentral Mackenzie District. Northwest Territories. Canadian Field-Natuialist 89 (2): 135-142.

'WEBER, W. C. 1976. Birds of north-central Manitoba. 197.3. Blue Jay 34: 84-94.

\section{PRAIRIE CHRISTMAS BIRD COUNTS, 1906 - 1941.}

MARY I. HOUSTON and C. STUART HOUSTON, 863 University Drive, Saskatoon, Saskatchewan. S7N 0J8.

In the December, 1900, issue of Bird Lore, editor Frank M. Chapman proposed a new type of Christmas day recreation to replace the sportsmen's "side hunt", whereby teams went out on Christmas day to see who could slaughter the greatest number of wild birds or animals. Chapman proposed that instead of slaughter, the birds be observed and the record be published in the first "Christmas Bird Census". Information as to weather, distance travelled, and hours in the field was requested, much as it is for Audubon counts today, although there were no restrictions as to minimum time.

In this paper we review Christmas Counts in the Prairie Provinces from 1906 through 1941. The year 1942 marked a new era in Christmas Counts, with Mrs. Priestly's announcement in the very first issue of the Blue Jay, soliciting entries to be published in the March issue. Sure enough, Volume 1, Number 2 con- tained eight counts - by Maurice G. Street of Nipawin, Frank Baines, southwest of Saltcoats, Jim Rogerson, visiting east of Saltcoats, F. Rouse of Scott, William Niven of Sheho, Steve Mann of Skull Creek, J. Francis Roy of Tullis and 5 adults and 4 juniors at Yorkton.

In the February, 1901; issue of Bird Lore, 25 counts were published. Two were from Canada; Fannie Jones saw four species in 5 hours in Toronto and William $\mathrm{H}$. Moore saw nine species in 1 hour at Scotch Lake, New Brunswick. There were no counts from Canada for Christmas, 1901. There were counts from Charlottetown. P.E.I. in 1902: Queenston, Ontario in 1903: Reaboro and Queenston in 1904 and Millsbrook, Reaboro and Queenston. Ontario in 1905. The first published count from the Prairie Provinces was taken by Sidney S. S. Stansell in Edmonton in $1906-11$ species in 8 hours. 